\title{
Efforts for maintaining rare, non commercial, native breeds in Hungary
}

\author{
J. DOHY, I. BODÓ and O. MÁTAY \\ Department of Animal Breeding, University of Veterinary Sciences, Budapest; \\ National Inspectorate for Feeding and Animal Production, Budapest, Hungary
}

In Hungary an official gene-conservation program is going on in order to purify, multiply and maintain rare native, endangered non-commercial breeds of cattle, sheep, pig, poultry, horse and dogs. Data are tabulated and selection and mating system is outlined. Importance of international cooperation and coordination in order to save such breeds of unique characteristics is stressed.

\section{Inbreeding and reproduction in small sized herds}

\author{
I. BODÓ, J. DOHY, Gy. KOVÁCS, G. SZÖLLÖSY, Erzsébet TAKÁCS \\ Department of Animal Breeding, University of Veterinary Sciences, Budapest \\ Research Institute for Animal Production, Herceghalom, Hungary
}

Changes of inbreeding and reproduction of Hungarian Grey cows were investigated in a relatively small population. Inbreeding was expressed by Wright's coefficient and blood group allele frequency. Under $10 \mathrm{p} .100$ of homozigosity no effect of inbreeding on reproduction could be observed. The difference between the inbred and not inbred part of population in reproductive performance was small and consequently in favour of the not inbred group. The number of « $B$ » blood group alleles was 29,21 and 14 in not inbred, inbred and intensively inbred group respectively. The different meaning of inbreeding coefficients on pedigree or on immunogenetic basis has been discussed.

\section{Genetic and economic differences between alternative methods of gene conservation (small populations, frozen semen and frozen embryos)}

\author{
G. BREM, F. GRAF, H. KRÄUSSLICH
}

Institut für Tierzucht und Tierhygiene, Veterinärstr. 13, D-8000 München 22, B.D.R.

The alternatives for the conservation of the genetic information - small population, frozen semen and frozen embryos - show differences in practicability and costs. Annual expenses for keeping rare breeds in small populations are very high and rate of inbreeding and the genetic drift cause genetic changes. Storing frozen semen and frozen embryos seems to be the best method. For the State of Bavaria a gene bank for Murnau-Werdenfelser, Braunvieh - old type, Gelbvieh und Fleckvieh is proposed and the costs are estimated. 